\title{
Elaboration of Octagonal Roses to represent the wind patterns in the Port de Veracruz during the last 10 years
}

\section{Elaboración de Rosas Octagonales para representar el comportamiento del viento en el Puerto de Veracruz durante los últimos 10 años}

\author{
GONZALEZ-JUAREZ Aníbal*†, AGUILAR-RAMIREZ Ana María, UTRERA-ZARATE, Alberto and \\ MOLINA-NAVARRO, Antonio
}

\section{Instituto Oceanográfico del Pacifico}

ID $1^{\text {st }}$ Author: Aníbal, González-Juárez / ORC ID: 0000-0002-7012-5277, CVU CONACYT ID: 1003848

ID $1^{\text {st }}$ Co-author: Ana María, Aguilar-Ramírez / ORC ID: 0000-0003-2867-8254, CVU CONACYT ID: 811392

ID $2^{\text {nd }}$ Co-author: Alberto, Utrera-Zarate / ORC ID: 0000-0002-6282-4449, CVU CONACYT ID: 365626

ID $3^{\text {rd }}$ Co-author: Antonio, Molina-Navarro / ORC ID: 0000-0001-7949-8371, CVU CONACYT ID: 811437

\begin{abstract}
The Port de Veracruz and its surroundings are affected by meteorological phenomena such as the passage of frontal systems, among others. The main objective of this writing is to carry out continuous monitoring to categorize wind behavior, in order to determine patterns in the last 10 years. Therefore, climatological records of the intensity and direction of the average wind speeds are presented; wind data from three Automatic Meteorological Surface Stations (EMAS) of the Meteorological Observation Network of the Secretariat of the Navy, one of the National Meteorological Service (SMN) and two buoys of the National Oceanic and Atmospheric Administration (NOAA) were processed and analyzed. The results indicated that the North $(\mathrm{N})$ direction predominately governs during the cold front season, while the East (E) winds predominately govern during the warm months (June, July, August and September). The maximum gusts, which can be an important factor in accidents, especially when their intensity exceeds 20 knots, affect various human, maritime, agricultural and livestock activities and tourism.
\end{abstract}

\begin{abstract}
Resumen
El puerto de Veracruz y sus inmediaciones se ven afectados por fenómenos meteorológicos como el paso de sistemas frontales, entre otros, el objetivo primordial del presente trabajo es efectuar la constante observación y evaluación para caracterizar el comportamiento del viento, con el fin de determinar la tendencia en los últimos 10 años. Por lo anterior, se presentan registros climatológicos de la intensidad y dirección del viento promedio; se procesaron y analizaron datos de viento provenientes de tres Estaciones Meteorológicas Automáticas de Superficie (EMAS) de la Red de Observación Meteorológica de la Secretaría de Marina, una del Servicio Meteorológico Nacional (SMN) y dos boyas de la Administración Nacional Oceánica y Atmosférica (NOAA). Los resultados indicaron que la dirección Norte $(\mathrm{N})$ predomina durante la temporada de frentes fríos, mientras que los vientos del Este (E) lo hace durante los meses cálidos (junio, julio, agosto y septiembre). Las ráfagas máximas, que pueden constituir un factor importante de accidentes, especialmente cuando su intensidad supera los 20 nudos ya que afecta a diversas actividades humanas, marítimas, agropecuarias y turismo.
\end{abstract}

Citación: GONZALEZ-JUAREZ Aníbal, AGUILAR-RAMIREZ Ana María, UTRERA-ZARATE, Alberto and MOLINANAVARRO, Antonio. Elaboration of Octagonal Roses to represent the wind patterns in the Port de Veracruz during the last 10 years. Journal of Experimental Systems. 2021. 8-24: 1-8

\footnotetext{
* Author Correspondence (anibal_goju@yahoo.com.mx).

$\dagger$ Researcher contributing as first author.
} 


\section{Introduction}

Wind is the movement of air in any direction and its magnitude can vary from a calm state to very intense winds (Tai, 2015); it is considered one of the most relevant variables due to its importance in different economic sectors. Such as maritime energy to mention one example; as wind can exert considerable force on some structures, such that some shipping operators limit operations when winds exceed 15 to 20 knots due to the formation of wind waves and the discomfort of crew and passengers, as well as threats to their safety (WMO, 2018). High winds create hazardous working conditions for personnel on exposed decks and affect survey platforms, loading and unloading operations, helipad, module access and general deck operations (WMO, 2018). For this reason, safety and security in Mexican ports must be strengthened and legal certainty must be provided to the maritime community.

The port of Veracruz is the oldest port in Mexico and, historically, the most significant in the country due to its equipment for the transport of vehicles imported or exported by sea and the movement of container cargo (APIVER 2021). In addition to being the best connected of the nation, which allows supplying 15 states of the Mexican Republic, which serves more than 67 million inhabitants and also has maritime routes to more than 150 ports in the world. It is also responsible for generating $11 \%$ of the national electricity (Silva-Casarín et al., 2018) and represents $37 \%$ of the national territory (INEGI, 1988). This port and its surroundings are affected by meteorological phenomena such as the passage of frontal systems and tropical waves, which makes it necessary to constantly observe and evaluate the behaviour of the wind (Calderón, 2017).

In order to fulfil this purpose and given the lack of climate characterisation and the importance it has for the exploitation of the country's natural resources, this work proposes a study of the behaviour of winds in the Port of Veracruz over the last 10 years, considering the recommendations of the World Maritime Organisation, which suggests constant monitoring of climatological variables and their representation in the form of maps, graphs and statistics, given that they are useful for numerous activities, ranging from navigation to the planning of various operations on the coast.
In order to serve as a useful reference tool for both promoting favourable maritime development and sustainable exploitation of resources in this geographical area. On the other hand, it is relevant to carry out the study of wind behaviour in the port of Veracruz, in order to have a recent analysis with which to determine the wind trend in recent years; also complying with the WMO regulations in which it specifies about local studies, in order to observe its variability.

\section{Methodology}

In order to characterise the wind over the port of Veracruz, the meteorological stations closest to the port of Veracruz were identified, six in total, which are described in Table 1, located in Figure 1.

\begin{tabular}{|c|c|c|}
\hline Station & Years & Period \\
\hline Heroic Military Naval School (HENM) & 10 & 2010-2019 \\
\hline Boca del Rio & 9 & $2010-2018$ \\
\hline Sacrificios & 8 & $2012-2019$ \\
\hline $\begin{array}{l}\text { Oceanographic Institute of the Gulf and } \\
\text { Caribbean Sea (IOGMC) }\end{array}$ & 3 & $2016-2019$ \\
\hline NOAA Buoy & 6 & 2011-2016 \\
\hline NOAA Sacrificios & 6 & $2011-2016$ \\
\hline
\end{tabular}

Table 1 Meteorological stations consulted Source (Own Elaboration)

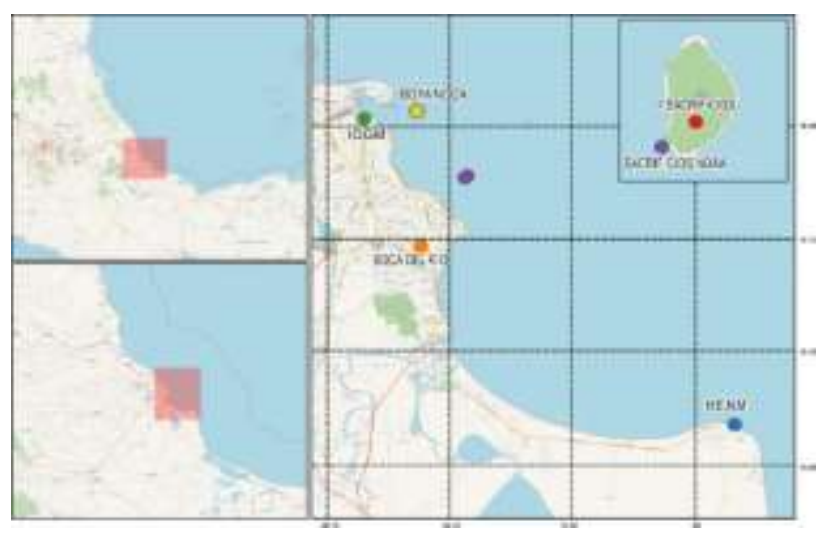

Figure 1 Location of stations used Source: Google Maps

Using the Python programming language, the wind data were cleaned, creating time, speed and direction matrices, in order to homogenise them in terms of format and structure. Due to the fact that the winds recorded by the EMAS and the buoys are in time intervals of $15 \mathrm{~min}$ and $60 \mathrm{~min}$, respectively, the following quality control actions were carried out to clean the database: 
a. Anomalous data were identified within each record and were taken as missing data

b. Records indicating more than 30 days without data were considered as missing.

c. Data where the sustained wind exceeded the gust were taken as erroneous data and were not used.

After the quality control actions and through descriptive statistics, the averages were obtained, identifying the dominant wind during the day. As the data recorded the direction in degrees, the components and their equivalence in degrees were identified in a wind rose. Working with the eight classical components and defining the intervals to have homogeneous directions.

Images were produced for a better interpretation of the information. These graphics were generated with the software Inkscape, which is a vector graphics editor, and with it, wind roses were made in an octagonal shape; thus obtaining the behaviour of the wind (direction and intensity) during the last 10 years in the port of Veracruz.

\section{Results and analysis}

The representation was carried out through octagonal shaped graphs, where each side of the geometric figure represents one of the wind components. Each of these sides is the base of a bar graph representing the monthly average wind frequency and the colour, based on the Beaufort scale, indicates the maximum average sustained wind that can be expected. Also, in the central part, it is shown if there was no wind, a situation known as calm periods.

Each of the images presented below has two support elements in the lower corners to be able to interpret them correctly, 1) lower right corner: shows the Beaufort scale in $\mathrm{km} / \mathrm{h}$ (Table 2 ), with their respective colours according to the intensity, which are used in the bars on each side of the octagonal, to show the average maximum sustained wind, 2) lower left corner the reference scale of the percentage units.

\begin{tabular}{|c|c|c|c|}
\hline Scale & $\begin{array}{l}\text { Speed } \\
(\mathbf{k m} / \mathbf{h})\end{array}$ & Designation Colour & $\begin{array}{l}\text { Designation } \\
\text { Colour }\end{array}$ \\
\hline 0 & $0-1$ & calm & \\
\hline 1 & 1 to 5 & Ventolina & \\
\hline 2 & 5 to 11 & Very weak breeze (weak) & \\
\hline 3 & 13 to 19 & Light Breeze (Light) & \\
\hline 4 & 19 to 28 & $\begin{array}{ll}\begin{array}{l}\text { Moderate } \\
\text { (Bonancible) }\end{array} & \text { breeze } \\
\end{array}$ & \\
\hline 5 & 28 to 38 & Fresh breeze (Fresquito) & \\
\hline 6 & 38 to 49 & Strong breeze (Fresco) & \\
\hline 7 & 49 to 61 & Strong wind (Frescachón) & \\
\hline 8 & 61 to 74 & Hard Wind (Temporary) & \\
\hline 9 & 74 to 88 & Strong wind (Very strong) & \\
\hline 10 & 88 to 102 & Strong Storm (Temporal) & \\
\hline 11 & 102 to 117 & Very strong storm (Squall) & \\
\hline 12 & +117 & $\begin{array}{l}\text { Hurricane } \\
\text { (Hurricane) }\end{array} \quad$ storm & \\
\hline
\end{tabular}

Table 2 BEAUFORT SCALE

Source: Directorate of Meteorology SEMAR

Figure 2 shows the percentage of wind direction for the data series 2010-2019. It should be noted that the HENM station is the most representative, as it presents the complete period during the 10 years.

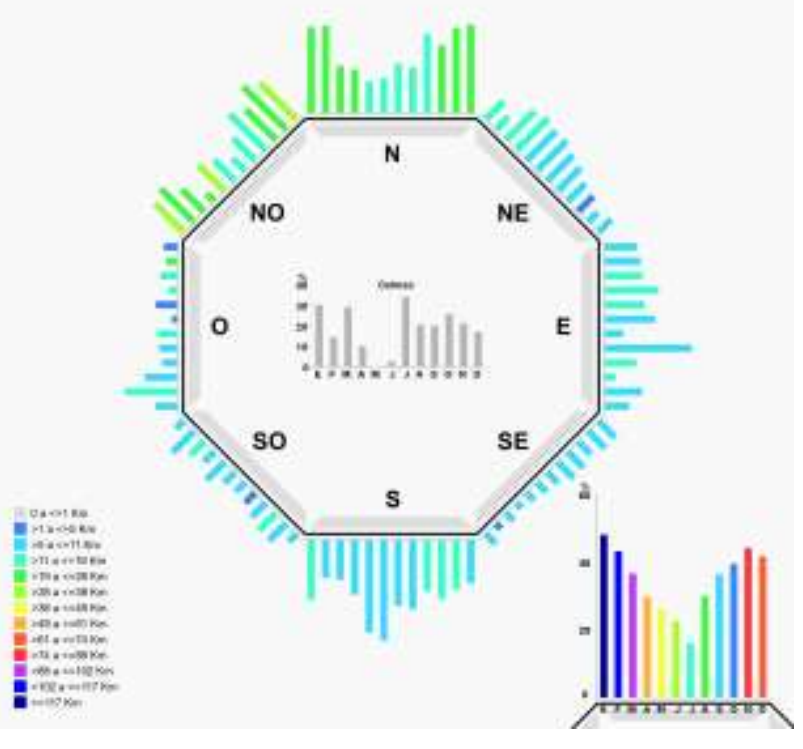

Figure 2 Percentage of wind direction at HENM station Source: Own Elaboration

In this station there is a variation in its wind regime, none of the 8 components reaches $50 \%$ of predominance in the year. However, the dominant direction is from the $\mathrm{N}$, with a frequency of $26.2 \%$ in the month of December. But this is followed by the NW and $\mathrm{S}$ components, with a percentage of $18 \%$ in the month of November and $29.8 \%$ in the month of July respectively. 
In this EMA it is important to point out that the winds have a great variability in the wind direction, but always with a predominance of the $\mathrm{N}$ and $\mathrm{S}$ sector, since in the other quadrants they have frequencies below $15 \%$. Likewise, the prevailing wind direction in the last 10 years at HENM has been $\mathrm{N}$.

The most notable characteristic in this place are the calms or air movement whose speed is zero or less than 2 knots, or what is the same as force 0 on the Beaufort scale, which shows that the month of May is the one with the lowest percentage of them with $0 \%$; which indicates that throughout this month the wind is perceptible, regardless of the direction. For the rest of the months it ranges between $14.3 \%$ and $30.1 \%$, with the sole exception of July, which is $33.9 \%$, a circumstance that coincides with the fact that July is when the lowest wind intensity is recorded. The percentage of calms tends to increase when the secondary courses try to match the dominant ones.

Figure 3 shows the percentage of wind direction at the Boca del Río station during the 2010-2018 data period.

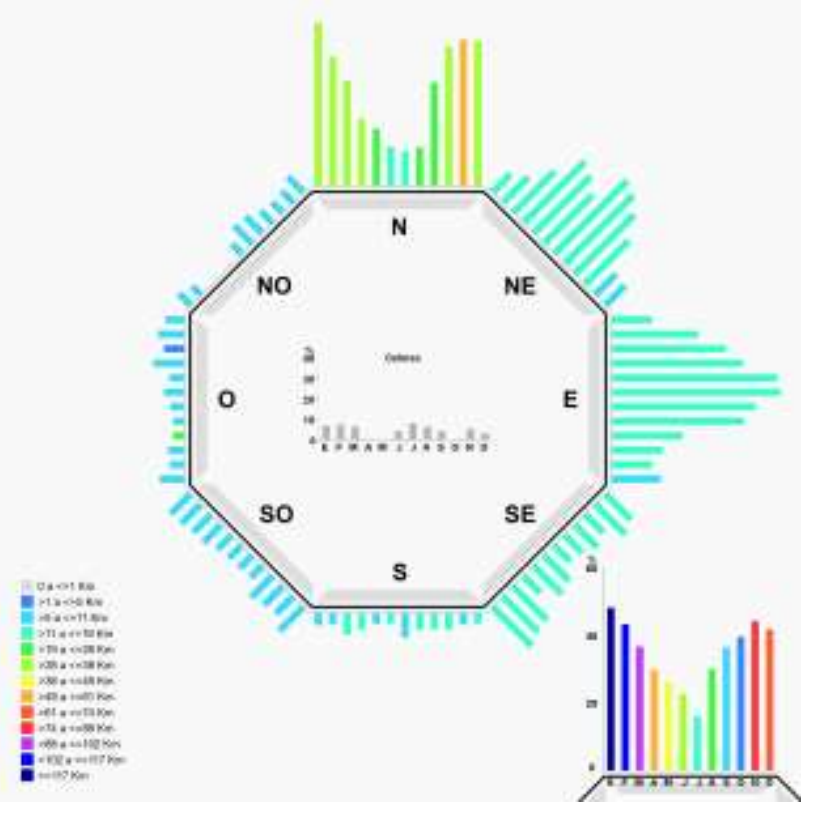

Figure 3 Percentage of wind direction at Boca del Río station

Source: Own Elaboration

It should be noted that this station is the second with the second highest number of real data. It shows an important incidence of winds coming from the North, followed by the Northeast and East.
From the month of September onwards, the winds from the $\mathrm{N}$ component persist in an ascending manner, being reflected in the month of November with maximum winds of $51.7 \mathrm{~km} / \mathrm{h}$ and in a descending manner that continues until the month of May. The NE and E components have an impact in the months of June, July and August. Likewise, the prevailing wind direction in the last 10 years at the Boca del Rio station is North.

Figure 4 shows the percentage of the wind direction of the station located in Isla de Sacrificios, for a period of observations 20122019. The most frequent direction is from the $\mathrm{N}$, followed by the E.

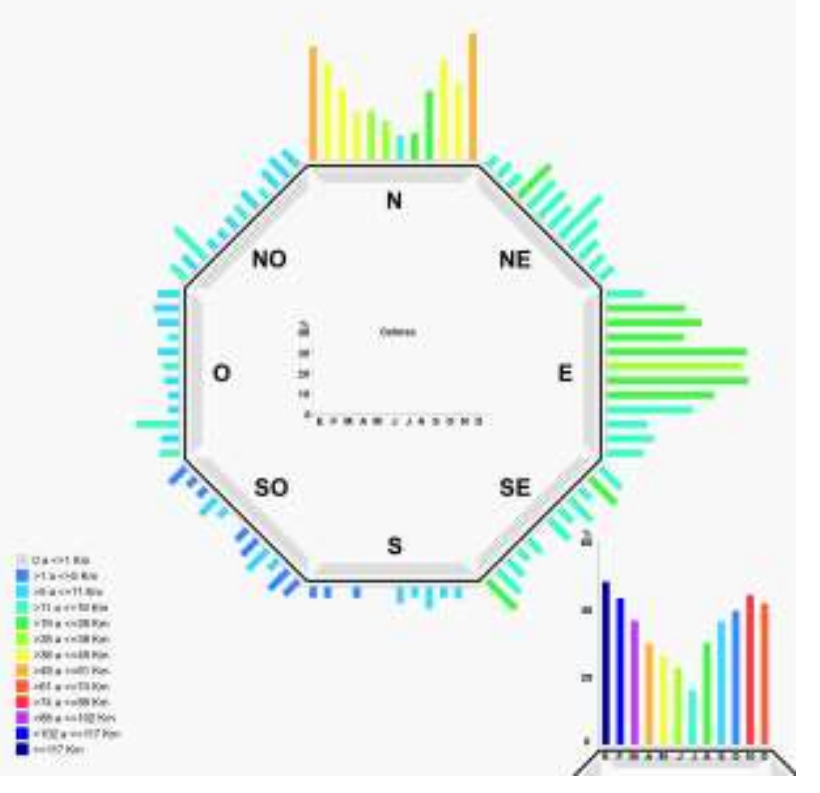

Figure 4 Percentage of wind direction at the Isla de Sacrificios station

Source: Own Elaboration

The most frequent directions are from the $\mathrm{N}$ and $\mathrm{E}$ with a percentage of $37.6 \%$ in December and $41.9 \%$ in July respectively. Winds from the SE (11.8\%) reached a notable frequency in December. The directions with a medium and low frequency are $\mathrm{S}(6.7 \%)$, SW $(6.0 \%), \mathrm{W}(8.3 \%)$ and NW (12.9\%).

In terms of wind speed, it is observed that the wind has exceeded degree 7 on the Beaufort scale, classified as strong wind; it is recorded in January and December where winds reach 54.6 $\mathrm{km} / \mathrm{h}$ and $57.1 \mathrm{~km} / \mathrm{hr}$ respectively; with July and August being on the opposite side of the scale. There are no calm periods. 
In this season, the season of frontal systems is fully manifested and is reflected in the intensity of its winds; on the other hand, the presence of easterly winds is appreciated both in percentage and intensity in the months of June, July and August. Likewise, the prevailing wind direction in the last 10 years at the Isla Sacrificios station has been from the $\mathrm{N}$ component.

Figure 5 shows the percentage of the wind direction of the station located in the IOGMC, for the period 2016-2019. It is important to point out that the data processing carried out at this station is not representative of a climatology; but in addition to this, an analysis was carried out in which the lack of data is very noticeable. However, they can be used to draw conclusions about the importance of the data and the action of the city, as this station is located in the urban centre.

But it stands out that the direction with the highest percentage is from the $\mathrm{N}$ and $\mathrm{NE}$, with an average of $33.9 \%$ in December and 53.8 $\%$ in July respectively. The calm periods are below $15 \%$, in the months of February, March, April and August. In terms of speed, the highest intensities are observed in December with 19 $\mathrm{km} / \mathrm{h}$. The lowest speeds are in December with $19 \mathrm{~km} / \mathrm{h}$. The lowest speeds are in the month of August.

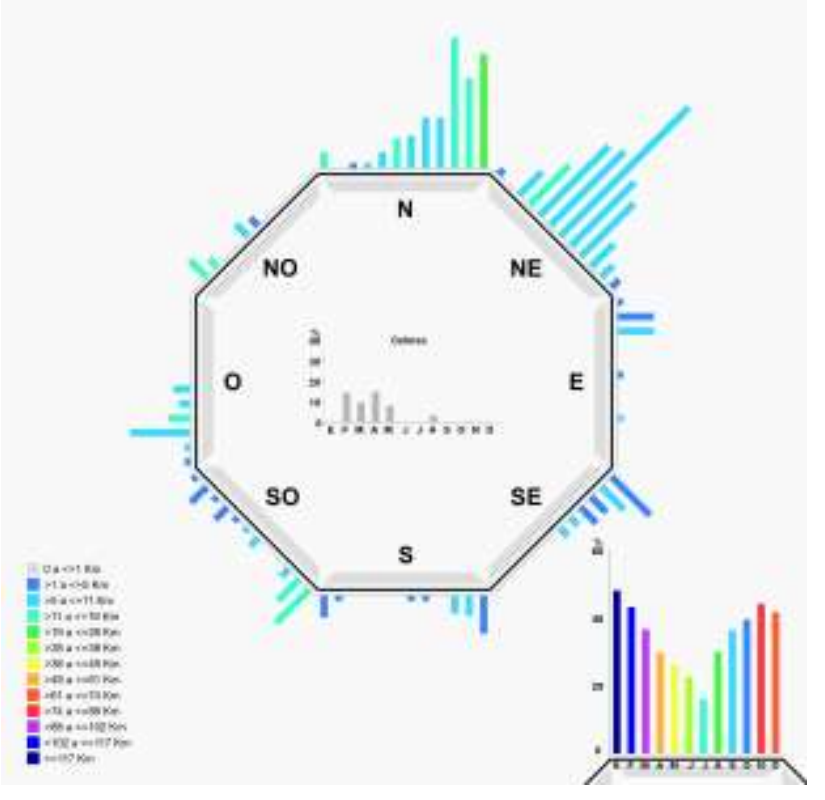

Figure 5 Wind direction percentage of the IOGMC station Source: Own Elaboration
In the analysis of this EMA, it is made clear that, given the lack of data, it is very difficult to characterise a variable; but this is not the objective of the study, which is why we do not go into detail regarding the characteristics of the station itself. However, the prevailing wind direction over the last 10 years at the IOMC station is NE.

Figure 6 shows the percentage of the NOAA Buoy wind direction in which there was wind by component, using all the observations for the period 2011-2016. The graph confirms, on the one hand, the dominance of $\mathrm{N}$ winds throughout the year, which reach their maximum percentage in the month of January; and on the other hand, winds from the Northeast and East as the second dominant component. The rest of the directions are considered secondary because they are below $20 \%$.

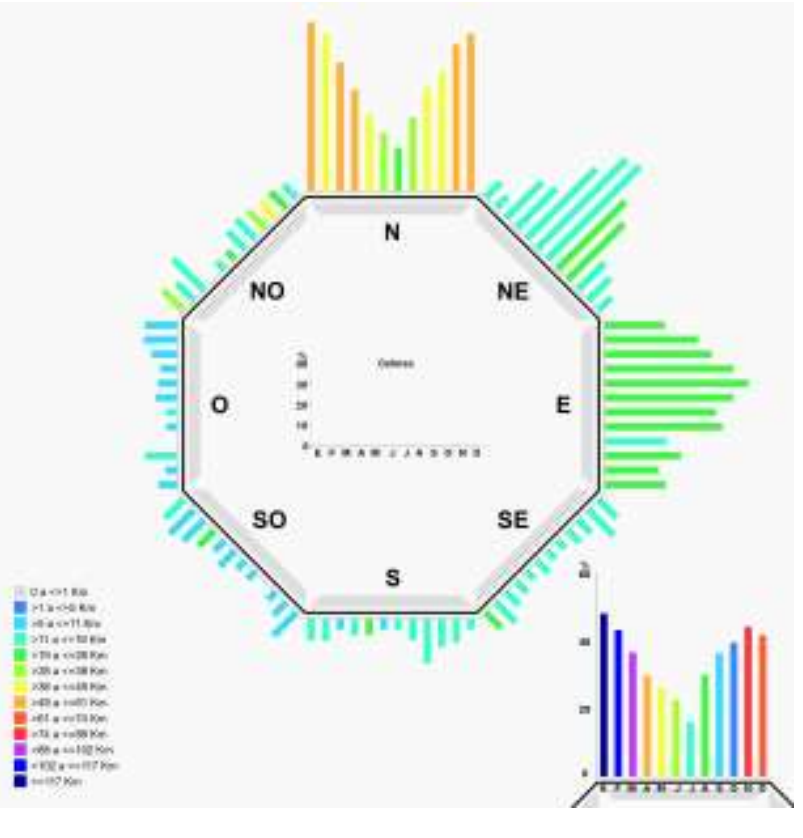

Figure 6 Percentage of wind direction at NOAA Buoy Source: Own Elaboration

The directions with the highest frequency are N, NE and E with a percentage in December $(50.0 \%)$, in July (38.7\%) and May (32.6\%) respectively. The directions with a low frequency are SE (3.2\%), S (3.2\%), SW (3.3\%), $\mathrm{W}(3.2 \%)$, and NW (3.2\%). At this station the wind speeds are observed to exceed degree 7 on the Beaufort scale (Table 2), classified as strong wind; it is recorded in November, December, January, April and May where the winds exceed $55 \mathrm{~km} / \mathrm{h}$. July is the month with the lowest wind intensity. Likewise, the prevailing wind direction over the last 10 years at the NOAA buoy is from the north. 
Figure 7 shows the percentage of wind direction at the NOAA Sacrificios station, using data from 2011-2016. It can be seen that the most frequent direction is $\mathrm{N}$ during the winter months, which have the highest intensities with values between 49 and $74 \mathrm{~km} / \mathrm{h}$ on average during that period; while the $\mathrm{NE}$ and $\mathrm{E}$ directions also occupy the second position, but unlike the first, these occur mostly during the summer months, as they are influenced by the trade winds. The percentage of calms is nil.

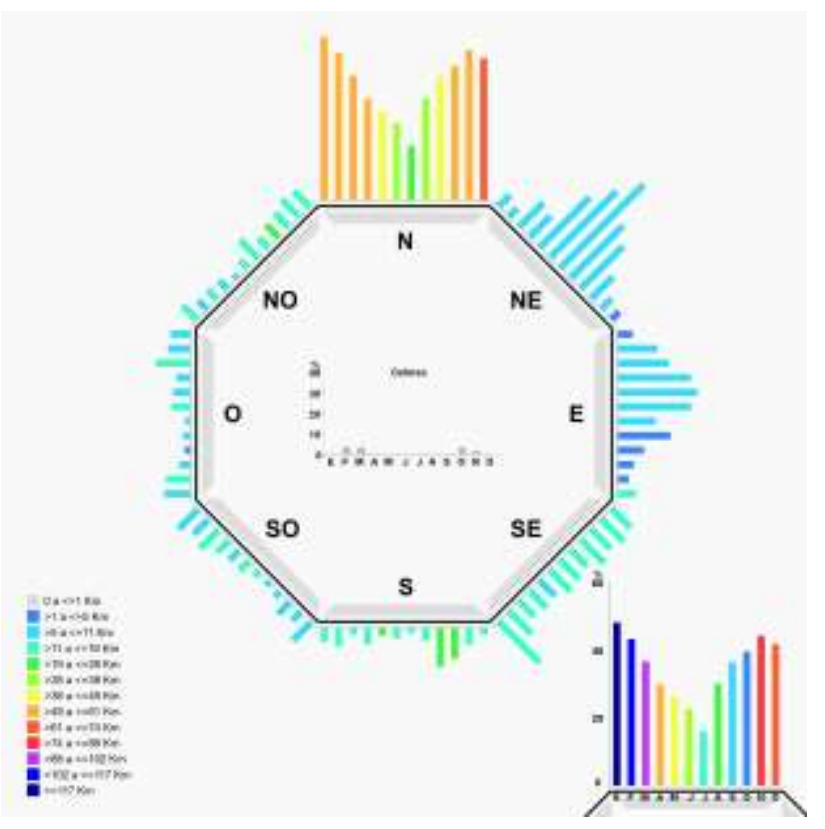

Figure 7 Percentage of wind direction at the NOAA Sacrificios station

Source: Own Elaboration

The most frequent directions are $\mathrm{N}$ and $\mathrm{NE}$ and $\mathrm{E}$ with a percentage in January (48.4\%), in July (34.9\%) and May (23.7\%) respectively. Winds from the SE (17.2\%) reached a notable frequency in December.

In terms of wind speed, it can be seen that the wind exceeds grade 8 on the Beaufort scale, classified as a hard wind; it is recorded in December $(62.5 \mathrm{~km} / \mathrm{h})$; the months of October, November, January, February, March and April have winds of grade 7 on the Beaufort scale. Likewise, the prevailing wind direction in the last 10 years at the Sacrificios NOAA station is from the $\mathrm{N}$ component.

The percentages of calm winds are low and are below 3\% in February, March, October and November. This buoy presents very similar data to EMA, which is located in Sacrificios Island.

\section{Conclusions}

Regarding the results obtained by studying the wind behaviour in the five stations and one buoy, it is evident to observe weak and moderate winds blowing in all directions in most months; although their percentages are very low, winds from the East and West are frequent; representing almost $50 \%$ in the stations of Boca del Río, Isla de Sacrificios, Isla de Sacrificios NOAA and Boya de la NOAA. This marked component is due to the local regime of sea breeze and continental breeze winds, which are present in synoptically stable conditions, as well as in the spring and summer seasons; which are the product of the difference in temperatures between the ocean-continent dichotomy, which cause pressure differences and consequently the wind that goes from high pressure to low pressure on surfaces.

In addition, during the months of June, July, August and September, it is observed that the easterly winds indicate a higher percentage and increase in wind speed, which means the possibility of the existence of a more accentuated sea breeze phenomenon over the area of the Port of Veracruz.

For the HENM, IOGC and Boca del Río stations, it is where the lowest wind intensities occurred, due to the fact that they are located within the urban area and the wind friction with the heterogeneities of the terrain, such as buildings, trees and small hills, causes the wind to decrease its speed or change its horizontal momentum flow to vertical.

Finally, the stations of Isla de Sacrificios, Isla de Sacrificios NOAA and the NOAA Buoy are where the wind registers the highest intensities (between 74 and $88 \mathrm{~km} / \mathrm{h}$ ), since these points are free of obstacles or barriers that diminish or deviate the intensity and direction of the wind, These intensities are present in the winter season with a northerly direction, which is considered the windiest season of the year, due to the air masses that move from polar areas towards the coast of the Gulf of Mexico (see figure 8). 


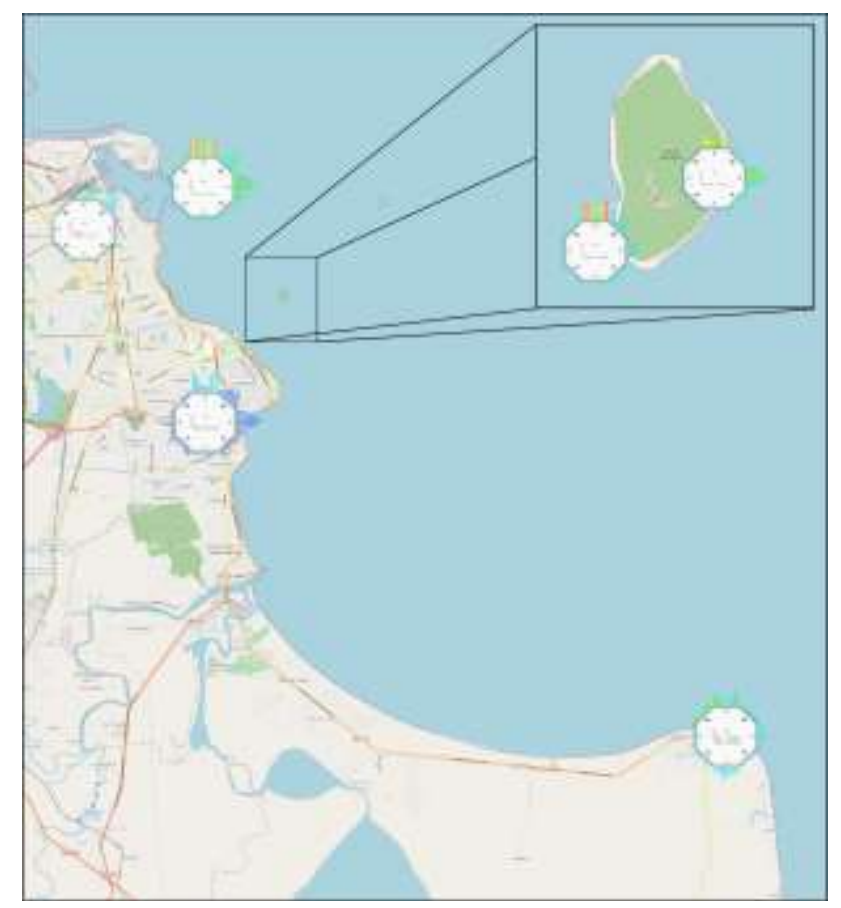

Figure 8 Octagonal roses representing the stations in the study area

Source: Google maps base map

\section{Recommendations}

The analysis and creation of wind roses for a quick and complete description of the climatic wind situation at a weather station should be put into practice in academia.

The institutions responsible for climatological data should emphasise the importance of having time series as complete as possible, since the periodic maintenance of these stations translates into good data.

\section{References}

Acevedo Rosas, Federico, y Antonio Luna DíazPeón. 2005. "Principales Fenómenos Meteorológicos que afectaron al estado de Veracruz en el Año 2005.”

Ahmed, M. M. Ibtihaj Abbas. 2017. "Denominaciones Científicas y Populares de Los Vientos."

OMM. 2018. Guía de Servicios Meteorológicos Marinos.

Arias Llanos, José, y Juan Cervantes Pérez. 1999. "Vientos Máximos En El Estado de Veracruz."

Diaz, Carlos Garrido. 2002. "Predicción de Datos Faltantes en Red de Estaciones Climatológicas."
Hernández-Escobedo, Quetzalcoatl, Francisco Espinosa-Arenal, Ricardo Saldaña-Flores, 2012. "Evaluación Del Potencial Eólico para la Generación de Energía Eléctrica en el Estado de Veracruz, México." DYNA (Colombia) 79(171):215-21.

Instituto Nacional de Estadística y Geografía. (1988). Síntesis Geográfica. Anexo Cartográfico del Estado de Veracruz. (pp. 69). Instituto Nacional de Estadística, Geografía e Informática.

Magaña, Victor, Luis Jose Pérez, Vazquez Luis Jorge, Carrisoza Eliseo, y Pérez Joel. 1999. "El Niño y El Clima." 23-68.

Mosiño, PA, E. García. 1974. "El Clima de México.” Londres: Elsevier 11:345-404.

Organización Mundial de Meteorologia. 2011. Guía de Prácticas Climatológicas. Vol. 100.

Pérez, Luis Manuel Santana. 2019. "Estudio Meteorológico en el Centro Insular. El Comportamiento del Viento en Tenerife. Primera Parte."

Román, A. N. A. Victoría. 2015. "Impactos sobre el Istmo Centroamericano"."

Secretaría de Protección Civil. 2017. "Calendario de Temporadas y Fenómenos Meteorológicos Para El Estado de Veracruz." 1.

Silva-Casarín, R., Moreno-Casasola, P., Martínez, Ma. L., Mendoza Baldwin, E., LópezPortillo, J., Lithgow, D., Vázquez, G., Martínez Martínez, R. E., Monroy Ibarra, R., Cáceres Puig, J. I., Ramírez Hernández, A., \& Boy Tamborrell, M. (2018). La zona costera del estado del estado de Veracruz. clima marítimo, medio físico y medio biótico (1st ed., pp. 9-70). Instituto De Ecología.

Tai, Osorio Elena. 2015. "Estudio de La Intensificación de Los Vientos En El Puerto de Veracruz Mediante Modelación Numérica." 1012.

Tejeda- Martinez Adalberto, 2004. "Circulación Local y Ascenso de Aire en un Sitio Costero y Tropical al Pie de la Montaña." Asociación Española de Climatología. 
Zamudio, Alfredo Ruiz Barradas y Adalberto Tejeda Martínez S, 2015. "Climatología." Anales de La Real Academia Nacional de Farmacia 81(5):84-100.

Zeng, Zhenzhong. 2018. "Global Terrestrial Stilling." Journal of Chemical Information and Modeling 53(9):1689-99.

APIVER. n.d. "APIVER - Administración Portuaria Integral de Veracruz." Retrieved (https://www.puertodeveracruz.com.mx/wordpr ess/blog/nuevo-record-2/). 